\title{
Excess dietary histidine decreases the liver copper level and serum alanine aminotransferase activity in Long-Evans Cinnamon rats
}

\author{
Hong Xu' ${ }^{1}$, Shoji Sakakibara ${ }^{1}$, Masashi Morifuji ${ }^{1}$, Quazi Salamatulla ${ }^{2}$ and Yoritaka Aoyama ${ }^{1 *}$ \\ ${ }^{1}$ Division of Applied Bioscience, Graduate School of Agriculture, Hokkaido University, Sapporo 060-8589, Japan \\ ${ }^{2}$ Institute of Nutrition and Food Science, Dhaka University, Dhaka-1000, Bangladesh
}

(Received 6 July 2002 - Revised 3 March 2003 - Accepted 15 May 2003)

\begin{abstract}
Long-Evans Cinnamon (LEC) rats spontaneously develop fulminant hepatitis, associated with excess $\mathrm{Cu}$ accumulation in the liver: thus, they are considered an animal model of Wilson's disease. In the present study, we investigated the ability of excess dietary histidine to reduce the excess accumulation of liver $\mathrm{Cu}$ in LEC rats by comparing them with Fischer rats. The results clearly showed that the excesshistidine diet markedly stimulated the $\mathrm{Cu}$ excretion in urine, and significantly decreased the liver $\mathrm{Cu}$ content in LEC rats by $47.5 \%$. The serum $\mathrm{Cu}$ content in LEC rats was not influenced by excess dietary histidine. We also compared the effects of excess dietary histidine on some liver antioxidant enzyme activities, liver and serum lipid levels and serum alanine aminotransferase activity of LEC and Fischer rats. Dietary histidine decreased the activities of total and $\mathrm{Cu}, \mathrm{Zn}$-superoxide dismutase in the liver of both strains. In LEC rats, the liver cholesterol content decreased, and serum cholesterol and phospholipids levels increased on feeding the excess-histidine diet. When fed on the basal diet, the serum alanine aminotransferase activity was higher in LEC rats than in Fischer rats, but a significant decrease in serum alanine aminotransferase activity of LEC rats was observed on feeding the excess-histidine diet. These results suggest that excess dietary histidine is effective in removing $\mathrm{Cu}$ ions from the liver of LEC rats. Thus, it may be of benefit in the prevention or treatment of liver injury in LEC rats and in patients with Wilson's disease.
\end{abstract}

Copper: Histidine: Alanine aminotransferase: Long-Evans Cinnamon rats

Long-Evans rats with a cinnamon-like colour (LEC rats) are an animal model of Wilson's disease, a hereditary disease caused by a mutation in the $\mathrm{Cu}$-transporting P-type ATPase gene (Wu et al. 1994). They show all the features of Wilson's disease, including excess $\mathrm{Cu}$ in the liver, reduced excretion of $\mathrm{Cu}$ into bile, reduced serum $\mathrm{Cu}$ and a remarkable decrease in serum caeruloplasmin activity (Li et al. 1991; Muramatsu et al. 1994). LEC rats spontaneously develop acute hepatitis at about 4 months of age and hepatocellular carcinoma from 1 year after birth. It has been demonstrated that excess hepatic $\mathrm{Cu}$ results in the development of liver injury in LEC rats (Masuda et al. 1988; Li et al. 1991; Sone et al. 1992; Mori et al. 1994). Chelation therapy, such as D-penicillamine, or feeding a $\mathrm{Cu}$-deficient diet can ameliorate the symptoms of LEC rats and Wilson's disease (Walshe, 1956; Sugawara et al. 1991a; Togashi et al. 1992; Klein et al. 2000). D-Penicillamine is the first-choice therapy for Wilson's disease (Loudianos \& Gitlin, 2000), but 25-30\% of patients show sensitivity to D-penicillamine in the form of rashes, fever, lymphadenopathy, leucopaenia or thrombocytopaenia, and a smaller number develop serious penicillamine toxicity with arthalgias, nephrotic syndrome, lupoid-like reactions and pemphigus (Steen et al. 1986).
Aoyama et al. (1999) showed that when Wistar rats were fed an excess-histidine diet (addition of $50 \mathrm{~g}$ L-histidine $/ \mathrm{kg}$ diet), urinary output of $\mathrm{Cu}$ markedly increased and the hepatic $\mathrm{Cu}$ content significantly decreased through the whole test period $(42 \mathrm{~d})$. This interesting observation prompted us to examine whether excess dietary histidine might reduce excess $\mathrm{Cu}$ accumulation in liver and thus to investigate other therapeutic approaches that might also be relevant to Wilson's disease. Thus, we supplied excess histidine in the diet of LEC rats to elucidate the effects of excess dietary histidine on $\mathrm{Cu}$ content in the liver, serum and urine, some liver antioxidant enzyme activities, liver and serum lipid levels, and serum alanine aminotransferase activity of LEC rats. We compared the results with those of Fischer rats.

\section{Materials and methods}

Animals and treatments

The present study complied with the Animal Experimental Guides according to the Committee of Experimental Animal Care, Hokkaido University. Two strains of male rats (LEC rats, Centre for Experimental Plants and 
Animals, Hokkaido University, Japan; Fischer rats, Japan SLC Inc., Hamamatsu, Shizuoka, Japan), with an initial body weight $108 \mathrm{~g}$, were housed individually in stainlesssteel wire-bottomed cages in an air-conditioned room kept at approximately $23^{\circ} \mathrm{C}$ and with a $12 \mathrm{~h}$ light-dark cycle (lights on at 08.00 hours). The initial ages of LEC and Fischer rats were about 54 and $49 \mathrm{~d}$ respectively. The rats in each strain were divided into two groups of six rats each and were provided ad libitum access to either the basal or excess-histidine diet and deionized-distilled water for $28 \mathrm{~d}$. The composition of the experimental diets is shown in Table 1. The excess-histidine diet was similar to the basal diet, except for the addition of $50 \mathrm{~g}$ L-histidine (Katayama Chemical Industries Co. Ltd, Osaka, Japan)/kg diet replacing an equal weight of maize starch. Body weight and food intake were measured each day during the whole experimental period.

After being fed for $28 \mathrm{~d}$, rats were killed by decapitation and blood samples were collected. The livers were immediately removed, weighed and frozen by dropping into liquid $\mathrm{N}_{2}$. Serum was prepared from blood samples by centrifuging at $3000 \mathrm{~g}$ for $10 \mathrm{~min}$. Samples of the liver and serum were stored at $-80^{\circ} \mathrm{C}$ until analysis. During days 13-14 and 27-28, urine was collected using metabolism cages.

\section{Measurements}

A sample of each liver was prepared by wet-ashing with concentrated $\mathrm{HNO}_{3}$ and subsequent complete digestion with $\mathrm{H}_{2} \mathrm{O}_{2}(300 \mathrm{ml} / \mathrm{l})$ (Forbes et al. 1983). $\mathrm{Cu}$ and $\mathrm{Zn}$ contents in the liver, serum and urine were estimated by atomic absorption spectrophotometer (Hitachi Ltd, 1978) using certified reference standards.

Superoxide dismutase activity was measured by the inhibition of Nitroblue Tetrazolium reduction mediated by the xanthine-xanthine oxidase-generated superoxide anions and monitored spectrophotometrically at $560 \mathrm{~nm}$ (McCord \& Fridovich, 1969). Samples of liver were homogenized using a Potter-Elvehjem type Teflon homogenizer (Tokyo Rikakikai Co. Ltd, Tokyo, Japan). The homogenizing

Table 1. Composition of experimental diets ( $\mathrm{g} / \mathrm{kg}$ diet)

\begin{tabular}{|c|c|c|}
\hline Ingredients & Basal diet* & $\begin{array}{c}\text { Excess-histidine } \\
\text { diet } \dagger\end{array}$ \\
\hline Casein $\ddagger$ & $250 \cdot 0$ & $250 \cdot 0$ \\
\hline L-Histidine§ & - & $50 \cdot 0$ \\
\hline Vitamin mixture (AIN-93G-VX)\| & $10 \cdot 0$ & $10 \cdot 0$ \\
\hline Choline bitartrate & 2.5 & 2.5 \\
\hline Mineral mixture (AIN-93G-MX)\| & $35 \cdot 0$ & $35 \cdot 0$ \\
\hline Soyabean oilq & $70 \cdot 0$ & $70 \cdot 0$ \\
\hline Maize starch** & $632 \cdot 5$ & 582.5 \\
\hline
\end{tabular}

* The diet was calculated to contain $17.4 \mathrm{MJ}$ digestible energy $/ \mathrm{kg}$ from the main ingredients (casein $16 \cdot 7$, soyabean oil $37 \cdot 6$, maize starch $16 \cdot 8 \mathrm{~kJ} / \mathrm{g}$ ).

†The diet was calculated to contain $17.4 \mathrm{MJ}$ digestible energy/kg from the main ingredients (casein 16.7, L-histidine 16.7, soyabean oil $37 \cdot 6$, maize starch $16.8 \mathrm{~kJ} / \mathrm{g}$ ).

$\ddagger$ New Zealand Dairy Board, Wellington, New Zealand.

§atayama Chemical Industries Co. Ltd, Osaka, Japan.

II Formulated according to Reeves et al. (1993).

I Wako Pure Chemical Industries Ltd, Osaka, Japan.

** Gelatinized; Chuo Shokuryo Co. Ltd, Inazawa, Aichi, Japan. buffer consisted of $0.25 \mathrm{M}$-sucrose, $0.5 \mathrm{~mm}$-EDTA and Triton X-100 (5 ml/1; pH 8.0). The homogenates were centrifuged at $5000 \mathrm{~g}$ for $20 \mathrm{~min}$. Mn-superoxide dismutase activity was inhibited by the addition of $0.2 \mathrm{~mm}-\mathrm{KCN}$ to the tissue homogenate. Total superoxide dismutase activity was measured without $\mathrm{KCN}$ solution. $\mathrm{Cu}, \mathrm{Zn}$-superoxide dismutase activity was calculated by the method of difference (total superoxide dismutase activity - Mn-superoxide dismutase activity). One unit of activity was defined as the amount of enzyme required to inhibit the rate of Nitroblue Tetrazolium reduction by $50 \%$.

Catalase activity was determined following $\mathrm{H}_{2} \mathrm{O}_{2}$ reduction as described by Aebi (1974). Samples of liver were homogenized using a Potter-Elvehjem type Teflon homogenizer. The homogenizing buffer consisted of $320 \mathrm{~mm}$-sucrose, $1 \mathrm{~mm}$-EDTA and $10 \mathrm{~mm}$-Tris- $\mathrm{HCl}(\mathrm{pH}$ 7.4). Homogenates were centrifuged at $12000 \mathrm{~g}$ for $30 \mathrm{~min}$. Using the supernatant fraction, catalase activity was measured spectrophotometrically at $240 \mathrm{~nm}$ and one unit of activity was defined as the amount of enzyme that liberated half the peroxide oxygen from an $\mathrm{H}_{2} \mathrm{O}_{2}$ solution per min.

Glutathione peroxidase activity was measured as the reduction of NADPH at $340 \mathrm{~nm}$ by the method of Paglia \& Valentine (1967). Liver samples were homogenized using the Potter-Elvehjem type Teflon homogenizer. The homogenizing buffer consisted of $50 \mathrm{~mm}$-Tris- $\mathrm{HCl}$, $5 \mathrm{~mm}$-EDTA, and $1 \mathrm{~mm}-2$-mercaptoethanol. Homogenates were centrifuged at $12000 \mathrm{~g}$ for $30 \mathrm{~min}$ at $4^{\circ} \mathrm{C}$. The supernatant fraction was used for measuring glutathione peroxidase activity. One unit of activity was defined as the amount of enzyme necessary to reduce $1 \mathrm{~mol} \mathrm{NADPH}$ per min.

The protein content was determined using bicinchoninic acid (Smith et al. 1985) with bovine serum albumin as the standard.

Hepatic lipids, extracted and purified by the method of Folch et al. (1957), were gravimetrically estimated after removing the solvent. Triacylglycerol (Nagele et al. 1985) and cholesterol (Siedel et al. 1983) in the liver were estimated by enzymatic methods. Phospholipids in the liver were calculated by the method of difference (total lipids - (triacylglycerol + cholesterol $)$ ). Serum triacylglycerol (Nagele et al. 1985), cholesterol (Siedel et al. 1983) and phospholipids (Takayama et al. 1977) were measured by enzymatic methods. For the calculation of concentration of triacylglycerol and phospholipids, molecular masses of 885.4 (triolein) and 786.1 (L- $\alpha$-phosphatidylcholine dioleoyl) were used for tricylglycerol and phospholipids respectively.

The activity of alanine aminotransferase was determined by the method of Wroblewski \& LaDue (1956).

\section{Statistical analysis}

Data were analysed by two-way ANOVA (Snedecor \& Cochran, 1989) with diet and strain as the independent variables, and significance of the differences between mean values was determined by Duncan's multiple range test (Duncan, 1955). A probability of $<0.05$ was considered significant. 
Table 2. Food intake ( $g / 28 \mathrm{~d})$, body-weight gain $(\mathrm{g} / 28 \mathrm{~d})$ and final liver weight ( $\mathrm{g} / \mathrm{kg}$ body weight) of rats fed the basal or excesshistidine diet $^{*}$

(Mean values with their standard errors for six rats per group)

\begin{tabular}{|c|c|c|c|c|c|c|c|c|}
\hline & \multicolumn{2}{|c|}{ Initial body weight } & \multicolumn{2}{|c|}{ Food intake } & \multicolumn{2}{|c|}{ Body-weight gain } & \multicolumn{2}{|c|}{ Liver weight } \\
\hline & Mean & $\mathrm{SE}$ & Mean & $\overline{\mathrm{SE}}$ & Mean & $\overline{\mathrm{SE}}$ & Mean & $\overline{\mathrm{SE}}$ \\
\hline \multicolumn{9}{|l|}{ LEC rats } \\
\hline Basal & $108 \cdot 3$ & $2 \cdot 5$ & $351^{\mathrm{a}}$ & 7 & $87 \cdot 3^{\mathrm{b}}$ & 5.9 & $31 \cdot 7^{c}$ & 0.7 \\
\hline Excess-histidine & $108 \cdot 1$ & 1.9 & $280^{\mathrm{b}}$ & 10 & $44 \cdot 0^{\mathrm{C}}$ & $7 \cdot 1$ & $39 \cdot 5^{\mathrm{b}}$ & $0 \cdot 7$ \\
\hline \multicolumn{9}{|l|}{ Fischer rats } \\
\hline Basal & $108 \cdot 1$ & 0.7 & $366^{a}$ & 9 & $127 \cdot 9^{a}$ & 3.4 & $40 \cdot 5^{\mathrm{b}}$ & 0.5 \\
\hline Excess-histidine & $108 \cdot 1$ & 0.7 & $286^{\mathrm{b}}$ & 8 & $87.7^{\mathrm{b}}$ & 3.0 & $47 \cdot 0^{\mathrm{a}}$ & 0.6 \\
\hline \multicolumn{9}{|c|}{ Statistical significance of effect (ANOVA, $P$ ) } \\
\hline \multicolumn{3}{|l|}{ Diet } & \multicolumn{2}{|c|}{$<0.001$} & \multicolumn{2}{|c|}{$<0.001$} & \multicolumn{2}{|c|}{$<0.001$} \\
\hline \multicolumn{3}{|l|}{ Strain } & \multicolumn{2}{|c|}{ NS } & \multicolumn{2}{|c|}{$<0.001$} & \multicolumn{2}{|c|}{$<0.001$} \\
\hline \multicolumn{3}{|l|}{ Diet $\times$ strain } & \multicolumn{2}{|c|}{ NS } & \multicolumn{2}{|c|}{ NS } & \multicolumn{2}{|c|}{ NS } \\
\hline
\end{tabular}

LEC, Long-Evans Cinnamon.

a,b,c Mean values within a column with unlike superscript letters were significantly different $(P<0.05)$.

${ }^{*}$ For details of diets and procedures, see Table 1 and p. 574.

\section{Results}

Food intake, body-weight gain and liver weight

Food intake, body-weight gain and liver weight of rats are shown in Table 2. The food intake of both strains of rats fed on the excess-histidine diet significantly decreased, but there was no significant difference between the two strains. The body-weight gains of both strains of rats was significantly decreased by feeding the excess-histidine diet. Body-weight gain was lower in LEC than in Fischer rats when fed on either the basal or excess-histidine diet. The liver weight of LEC rats was significantly lower than that of Fischer rats when fed on the excess-histidine diet. Both strains of rats had significantly increased liver weights compared with those fed the basal diet.

\section{Liver copper and zinc concentrations}

$\mathrm{Cu}$ and $\mathrm{Zn}$ concentrations in the livers of rats are shown in Table 3. Those in the liver of LEC rats fed the basal diet were about 62.90 and 2.85 times greater than those of Fischer rats respectively. In the livers of LEC rats fed the excess-histidine diet, the $\mathrm{Cu}$ and $\mathrm{Zn}$ concentrations were significantly reduced to 52.5 and $67.5 \%$ of those fed the basal diet, although they were still higher than those of Fischer rats.

\section{Serum copper and zinc concentrations}

$\mathrm{Cu}$ and $\mathrm{Zn}$ concentrations in serum of rats are shown in Table 4. Those in LEC rats fed on the basal diet were significantly lower than those of Fischer rats fed on the basal diet. The excess-histidine diet decreased serum $\mathrm{Cu}$ and $\mathrm{Zn}$ concentrations in Fischer rats, but did not influence those in LEC rats.

\section{Urine copper and zinc concentrations}

$\mathrm{Cu}$ and $\mathrm{Zn}$ concentrations in the urine of rats are shown in Table 5. The excess-histidine diet markedly stimulated the urinary output of $\mathrm{Cu}$ and $\mathrm{Zn}$ in both strains of rats. During the first period, $\mathrm{Cu}$ and $\mathrm{Zn}$ concentrations in the urine of
Table 3. Copper and zinc concentrations ( $\mu \mathrm{mol} / \mathrm{g}$ liver) in the livers of rats fed the basal or excess-histidine diet ${ }^{\star}$

(Mean values with their standard errors for six rats per group)

\begin{tabular}{|c|c|c|c|c|}
\hline & \multicolumn{2}{|c|}{ Copper } & \multicolumn{2}{|c|}{ Zinc } \\
\hline & Mean & SE & Mean & SE \\
\hline \multicolumn{5}{|l|}{ LEC rats } \\
\hline Basal & $3.56^{\mathrm{a}}$ & 0.27 & $1.03^{\mathrm{a}}$ & 0.05 \\
\hline Excess-histidine & $1.87^{b}$ & $0 \cdot 16$ & $0.695^{b}$ & 0.039 \\
\hline \multicolumn{5}{|l|}{ Fischer rats } \\
\hline Basal & $0.0566^{c}$ & 0.0017 & $0.362^{\mathrm{C}}$ & 0.011 \\
\hline Excess-histidine & $0.0349^{c}$ & 0.0012 & $0.374^{\mathrm{C}}$ & 0.006 \\
\hline \multicolumn{5}{|c|}{ Statistical significance of effect (ANOVA, $P$ ) } \\
\hline Diet & \multicolumn{2}{|c|}{$<0.001$} & \multicolumn{2}{|c|}{$<0.001$} \\
\hline Strain & \multicolumn{2}{|c|}{$<0.001$} & \multicolumn{2}{|c|}{$<0.001$} \\
\hline Diet $\times$ strain & \multicolumn{2}{|c|}{$<0.001$} & \multicolumn{2}{|c|}{$<0.001$} \\
\hline
\end{tabular}

LEC, Long-Evans Cinnamon.

$\mathrm{a}, \mathrm{b}, \mathrm{c}$ Mean values within a column with unlike superscript letters were significantly different $(P<0.05)$.

* For details of diets and procedures, see Table 1 and p. 574.

Table 4. Serum copper and zinc concentrations $(\mathrm{nmol} / \mathrm{ml})$ in rats fed the basal or excess-histidine diet $^{*}$

(Mean values with their standard errors for six rats per group)

\begin{tabular}{|c|c|c|c|c|}
\hline & \multicolumn{2}{|c|}{ Copper } & \multicolumn{2}{|c|}{ Zinc } \\
\hline & Mean & SE & Mean & SE \\
\hline \multicolumn{5}{|l|}{ LEC rats } \\
\hline Basal & $1.91^{\mathrm{c}}$ & 0.19 & $26 \cdot 5^{b}$ & $1 \cdot 1$ \\
\hline Excess-histidine & $2 \cdot 78^{c}$ & 0.26 & $27 \cdot 9^{b}$ & $2 \cdot 8$ \\
\hline \multicolumn{5}{|l|}{ Fischer rats } \\
\hline Basal & $17 \cdot 5^{\mathrm{a}}$ & 0.4 & $36 \cdot 3^{a}$ & 1.5 \\
\hline Excess-histidine & $14 \cdot 7^{b}$ & 1.4 & $25 \cdot 0^{b}$ & 0.5 \\
\hline \multicolumn{5}{|c|}{ Statistical significance of effect (ANOVA, $P$ ) } \\
\hline Diet & \multirow{2}{*}{\multicolumn{2}{|c|}{ NS }} & \multicolumn{2}{|c|}{$<0.01$} \\
\hline Strain & & & \multicolumn{2}{|c|}{ NS } \\
\hline Diet $\times$ strain & \multicolumn{2}{|c|}{$<0.05$} & \multicolumn{2}{|c|}{$<0.01$} \\
\hline
\end{tabular}

LEC, Long-Evans Cinnamon.

${ }^{\mathrm{a}, \mathrm{b}, \mathrm{c}}$ Mean values within a column with unlike superscript letters were significantly different $(P<0.05)$.

${ }^{*}$ For details of diets and procedures, see Table 1 and p. 574. 
LEC rats were similar to those of Fischer rats when fed on the basal diet, but when fed on the excess-histidine diet, the urinary excretion of $\mathrm{Cu}$ and $\mathrm{Zn}$ in LEC rats was significantly higher than that of Fischer rats. During the second period, $\mathrm{Cu}$ and $\mathrm{Zn}$ concentrations in the urine of LEC and Fischer rats were similar when fed on either the basal or excess-histidine diet.

\section{Liver superoxide dismutase, catalase and glutathione peroxidase activities}

Superoxide dismutase, catalase and glutathione peroxidase activities in the liver are shown in Table 6. The activities of total superoxide dismutase and $\mathrm{Cu}, \mathrm{Zn}$-superoxide dismutase in the liver of rats fed on the excess-histidine diet were significantly decreased in both LEC and Fischer rats. The Mn-superoxide dismutase activity in the liver of
Fischer rats fed on the excess-histidine diet significantly decreased. When fed on the basal diet, the activities of total, $\mathrm{Mn}$ - and $\mathrm{Cu}, \mathrm{Zn}$-superoxide dismutases were lower in LEC rats than in Fischer rats. When fed on the excess-histidine diet, total superoxide dismutase activity of LEC rats was lower than that of Fischer rats, but Mnand $\mathrm{Cu}, \mathrm{Zn}$-superoxide dismutase activities were similar in both strains.

The activity of catalase in the liver was not significantly different between rats fed the basal and excess-histidine diets, but that of Fischer rats was markedly higher than that of LEC rats. The activities of glutathione peroxidase in the liver of both strains were similar between those fed on the basal and excess-histidine diet. When fed on the basal diet, the activity of glutathione peroxidase in the liver of LEC rats was lower than that of Fischer rats. However, the activity of glutathione peroxidase was

Table 5. Urine copper and zinc concentrations ( $\mu \mathrm{mol} / \mathrm{kg}$ body weight per $2 \mathrm{~d}$ ) in rats fed the basal or excess-histidine diet ${ }^{\star}$

(Mean values with their standard errors for six rats per group)

\begin{tabular}{|c|c|c|c|c|c|c|c|c|}
\hline & \multicolumn{4}{|c|}{ 1st period (days 13-14) } & \multicolumn{4}{|c|}{ 2nd period (days $27-28$ ) } \\
\hline & \multicolumn{2}{|c|}{ Copper } & \multicolumn{2}{|c|}{ Zinc } & \multicolumn{2}{|c|}{ Copper } & \multicolumn{2}{|c|}{ Zinc } \\
\hline & Mean & SE & Mean & SE & Mean & SE & Mean & SE \\
\hline \multicolumn{9}{|l|}{ LEC rats } \\
\hline Basal & $2 \cdot 50^{\mathrm{C}}$ & 0.18 & $0.71^{\mathrm{c}}$ & $0 \cdot 10$ & $2 \cdot 45^{\mathrm{b}}$ & 0.53 & $0.70^{\mathrm{b}}$ & 0.08 \\
\hline Excess-histidine & $13 \cdot 0^{\mathrm{a}}$ & $1 \cdot 3$ & $81 \cdot 0^{\mathrm{a}}$ & $3 \cdot 4$ & $9 \cdot 59^{\mathrm{a}}$ & $1 \cdot 86$ & $56 \cdot 7^{\mathrm{a}}$ & $11 \cdot 1$ \\
\hline \multicolumn{9}{|l|}{ Fischer rats } \\
\hline Basal & $1.81^{\mathrm{C}}$ & 0.08 & $0.92^{c}$ & 0.11 & $1.82^{\mathrm{b}}$ & 0.09 & $0.72^{\mathrm{b}}$ & 0.08 \\
\hline Excess-histidine & $7 \cdot 82^{\mathrm{b}}$ & 0.25 & $64 \cdot 3^{\mathrm{b}}$ & $2 \cdot 9$ & $7 \cdot 34^{a}$ & 0.57 & $58 \cdot 2^{\mathrm{a}}$ & 1.6 \\
\hline \multicolumn{9}{|c|}{ Statistical significance of effect (ANOVA, $P$ ) } \\
\hline & \multirow{2}{*}{\multicolumn{2}{|c|}{$<0.001$}} & \multirow{2}{*}{\multicolumn{2}{|c|}{$<0.001$}} & \multirow{2}{*}{\multicolumn{2}{|c|}{$\begin{array}{c}<0.001 \\
\text { NS }\end{array}$}} & \multirow{2}{*}{\multicolumn{2}{|c|}{ NS }} \\
\hline Strain & & & & & & & & \\
\hline Diet $\times$ strain & \multicolumn{2}{|c|}{$<0.01$} & \multicolumn{2}{|c|}{$<0.01$} & \multicolumn{2}{|c|}{ NS } & \multicolumn{2}{|c|}{ NS } \\
\hline
\end{tabular}

LEC, Long-Evans Cinnamon.

a,b,c Mean values within a column with unlike superscript letters were significantly different $(P<0.05)$.

${ }^{*}$ For details of diets and procedures, see Table 1 and p. 574.

Table 6. Liver superoxide dismutase, catalase and glutathione peroxidase activities ( $\mathrm{U} / \mathrm{mg}$ protein) in rats fed the basal or excess-histidine diet*

(Mean values with their standard errors for six rats per group)

\begin{tabular}{|c|c|c|c|c|c|c|c|c|c|c|}
\hline & \multicolumn{6}{|c|}{ Superoxide dismutase } & & & & \\
\hline & \multicolumn{2}{|c|}{ Total } & \multicolumn{2}{|c|}{ Mn- } & \multicolumn{2}{|c|}{$\mathrm{Cu}, \mathrm{Zn}-$} & \multicolumn{2}{|c|}{ Catalase } & \multicolumn{2}{|c|}{$\begin{array}{l}\text { Glutathione } \\
\text { peroxidase }\end{array}$} \\
\hline & Mean & SE & Mean & SE & Mean & $\mathrm{SE}$ & Mean & SE & Mean & SE \\
\hline \multicolumn{11}{|l|}{ LEC rats } \\
\hline Basal & $9 \cdot 31^{\mathrm{b}}$ & 0.25 & $2.44^{\mathrm{b}}$ & 0.08 & $6 \cdot 87^{\mathrm{b}}$ & 0.25 & $112^{\mathrm{b}}$ & 5 & $0.862^{\mathrm{b}}$ & 0.032 \\
\hline Excess-histidine & $8 \cdot 41^{\mathrm{c}}$ & 0.24 & $2 \cdot 41^{\mathrm{b}}$ & 0.08 & $6 \cdot 00^{c}$ & 0.20 & $102^{\mathrm{b}}$ & 5 & $0.970^{\mathrm{ab}}$ & 0.049 \\
\hline \multicolumn{11}{|l|}{ Fischer rats } \\
\hline Basal & $10 \cdot 4^{a}$ & 0.3 & $2 \cdot 86^{\mathrm{a}}$ & 0.14 & $7 \cdot 56^{\mathrm{a}}$ & 0.23 & $285^{\mathrm{a}}$ & 8 & $1.09^{a}$ & 0.031 \\
\hline Excess-histidine & $8 \cdot 91^{\mathrm{b}}$ & $0 \cdot 11$ & $2.51^{\mathrm{b}}$ & 0.08 & $6 \cdot 40^{\mathrm{bc}}$ & 0.13 & $286^{\mathrm{a}}$ & 14 & $1.09^{\mathrm{a}}$ & 0.067 \\
\hline \multicolumn{11}{|c|}{ Statistical significance of effect (ANOVA, $P$ ) } \\
\hline Diet & \multirow{2}{*}{\multicolumn{2}{|c|}{$\begin{array}{l}<0.001 \\
<0.01\end{array}$}} & \multirow{2}{*}{\multicolumn{2}{|c|}{$\begin{array}{c}\text { NS } \\
<0.05\end{array}$}} & \multicolumn{2}{|c|}{$<0.001$} & \multicolumn{2}{|c|}{ NS } & \multirow{2}{*}{\multicolumn{2}{|c|}{$\begin{array}{c}\text { NS } \\
<0.01\end{array}$}} \\
\hline Strain & & & & & \multirow{2}{*}{\multicolumn{2}{|c|}{$\begin{array}{l}<0.05 \\
\text { NS }\end{array}$}} & & & & \\
\hline Diet $\times$ strain & \multicolumn{2}{|c|}{ NS } & \multicolumn{2}{|c|}{ NS } & & & \multicolumn{2}{|c|}{ NS } & \multicolumn{2}{|c|}{ NS } \\
\hline
\end{tabular}

LEC, Long-Evans Cinnamon.

a,b,c Mean values within a column with unlike superscript letters were significantly different $(P<0.05)$.

${ }^{*}$ For details of diets and procedures, see Table 1 and p. 574. 
similar between LEC and Fischer rats when fed on the excess-histidine diet.

\section{Liver total lipids, triacylglycerol, cholesterol and phospholipids concentrations}

Lipid concentrations in the liver of rats are shown in Table 7. The concentrations of total lipids, triacylglycerol and phospholipids in the liver of LEC rats were not significantly different from those fed on the basal and excess-histidine diets. The cholesterol concentration in the liver of LEC rats fed on the excess-histidine diet was significantly lower. In Fischer rats, feeding the excess-histidine diet significantly increased the concentrations of total lipids, triacylglycerol and cholesterol in the liver. The content of phospholipids in the liver of Fischer rats fed on the excess-histidine diet was similar to that of the basal diet. When fed on the basal diet, the concentrations of total lipids, triacylglycerol, cholesterol and phospholipids were not different between the two strains. However, when fed on the excess-histidine diet, the concentrations of total lipids, triacylglycerol and cholesterol in the livers of LEC rats were significantly lower than those of Fischer rats, and the concentrations of phospholipids in the livers were similar in both strains.

\section{Serum triacylglycerol, cholesterol and phospholipids concentrations}

The levels of triacylglycerol, cholesterol and phospholipids in the serum are shown in Table 8. The levels of cholesterol and phospholipids in the serum of LEC and Fischer rats fed on the excess-histidine diet significantly increased. Triacylglycerol level in the serum of Fischer rats significantly decreased on feeding the excess-histidine diet, but serum triacylglycerol level was not affected in LEC rats. When fed on the basal diet, the levels of triacylglycerol and phospholipids in the serum of LEC rats were significantly lower than those of Fischer rats, and cholesterol level was similar in both strains. On the excess-histidine diet, the levels of cholesterol and phospholipids in the serum of LEC rats were lower than those of Fischer rats, and triacylglycerol level was similar in both strains.

\section{Serum alanine aminotransferase activity}

Alanine aminotransferase activity in the serum is shown in Table 9. As compared with Fischer rats, serum alanine aminotransferase activity of LEC rats was higher when fed on the basal diet, and there was no difference between the strains when fed on the excess-histidine diet. Feeding of the excess-histidine diet to LEC rats, but not to Fischer rats, decreased the activity of alanine aminotransferase in the serum.

\section{Discussion}

The large amount of $\mathrm{Cu}$ accumulated in the livers of the LEC rats, an animal model of Wilson's disease, was also observed by Li et al. (1991) and Muramatsu et al. (1994) (Table 3); this also occurs in Wilson's disease. The key therapeutic strategy of Wilson's disease is to reduce the amount of $\mathrm{Cu}$ in the liver and other tissues by administering $\mathrm{Cu}$-chelating agents (Rakela et al. 2002). In addition to accumulation in the liver, $\mathrm{Cu}$ also accumulates in the brain and cornea of patients with Wilson's disease; however, this does not occur in LEC rats (Mori et al. 1994). Our aim was, therefore, to reduce the $\mathrm{Cu}$ in the liver of LEC rats with histidine as a chelator of metal ions. Similarly to D-penicillamine, histidine can chelate $\mathrm{Cu}$ to form stable complexes, which are readily excreted by the kidneys (Aoyama et al. 1992). As shown in Tables 3 and 5, after LEC rats were fed on the excess-histidine diet for $28 \mathrm{~d}$, the excess $\mathrm{Cu}$ accumulation in the liver was markedly reduced and urinary $\mathrm{Cu}$ excretion increased. These effects were similar to the report of Togashi et al. (1992), who administered D-penicillamine $(100 \mathrm{mg} / \mathrm{kg}$ body weight perd) to LEC rats for 12 weeks. However, the administration of D-penicillamine also decreased serum $\mathrm{Cu}$ concentration of LEC rats (Togashi et al. 1992). In contrast, no significant change of serum $\mathrm{Cu}$ level was found in LEC rats fed on the excess-histidine diet (Table 4).

Table 7. Liver total lipids (mg/g liver), triacylglycerol ( $\mu \mathrm{mol} / \mathrm{g}$ liver), cholesterol ( $\mu \mathrm{mol} / \mathrm{g}$ liver) and phospholipids $(\mu \mathrm{mol} / \mathrm{g}$ liver) in rats fed the basal or excess-histidine diet*

(Mean values with their standard errors for six rats per group)

\begin{tabular}{|c|c|c|c|c|c|c|c|c|}
\hline & \multicolumn{2}{|c|}{ Total lipids } & \multicolumn{2}{|c|}{ Triacylglycerol } & \multicolumn{2}{|c|}{ Cholesterol } & \multicolumn{2}{|c|}{ Phospholipids } \\
\hline & Mean & SE & Mean & SE & Mean & SE & Mean & SE \\
\hline \multicolumn{9}{|l|}{ LEC rats } \\
\hline Basal & $50 \cdot 2^{b}$ & 3.6 & $13 \cdot 1^{b}$ & $1 \cdot 3$ & $5 \cdot 09^{b}$ & 0.26 & $46 \cdot 6$ & $4 \cdot 3$ \\
\hline Excess-histidine & $44 \cdot 2^{b}$ & 3.3 & $5 \cdot 64^{b}$ & 0.93 & $3.91^{\mathrm{c}}$ & 0.15 & $48 \cdot 0$ & $4 \cdot 1$ \\
\hline \multicolumn{9}{|l|}{ Fischer rats } \\
\hline Basal & $52 \cdot 1^{b}$ & $3 \cdot 1$ & $18 \cdot 1^{b}$ & 1.0 & $5 \cdot 55^{\mathrm{b}}$ & 0.20 & $43 \cdot 1$ & $3 \cdot 6$ \\
\hline Excess-histidine & $78 \cdot 2^{\mathrm{a}}$ & $8 \cdot 7$ & $37 \cdot 3^{a}$ & $9 \cdot 6$ & $6 \cdot 64^{a}$ & 0.31 & $54 \cdot 2$ & 3.5 \\
\hline \multicolumn{9}{|c|}{ Statistical significance of effect (ANOVA, $P$ ) } \\
\hline Diet & \multirow{2}{*}{\multicolumn{2}{|c|}{$\begin{array}{l}\text { NS } \\
<0.01\end{array}$}} & \multicolumn{2}{|c|}{ NS } & \multicolumn{2}{|c|}{ NS } & \multicolumn{2}{|c|}{ NS } \\
\hline Strain & & & \multirow{2}{*}{\multicolumn{2}{|c|}{$<0.01$}} & \multicolumn{2}{|c|}{$<0.001$} & \multicolumn{2}{|c|}{ NS } \\
\hline Diet $\times$ strain & \multicolumn{2}{|c|}{$<0.01$} & & $<0.05$ & \multicolumn{2}{|c|}{$<0.001$} & \multicolumn{2}{|c|}{ NS } \\
\hline
\end{tabular}

LEC, Long-Evans Cinnamon.

a,b,c Mean values within a column with unlike superscript letters were significantly different $(P<0.05)$

${ }^{*}$ For details of diets and procedures, see Table 1 and p. 574. 
Table 8. Serum triacylglycerol $(\mathrm{mmol} / \mathrm{l})$, cholesterol $(\mathrm{mmol} / \mathrm{l})$ and phospholipids $(\mathrm{mmol} / \mathrm{l})$ in rats fed the basal or excess-histidine diet ${ }^{\star}$

(Mean values with their standard errors for six rats per group)

\begin{tabular}{|c|c|c|c|c|c|c|}
\hline & \multicolumn{2}{|c|}{$\begin{array}{l}\text { Triacyl- } \\
\text { glycerol }\end{array}$} & \multicolumn{2}{|c|}{ Cholesterol } & \multicolumn{2}{|c|}{$\begin{array}{l}\text { Phospho- } \\
\text { lipids }\end{array}$} \\
\hline & Mean & SE & Mean & SE & Mean & SE \\
\hline \multicolumn{7}{|l|}{ LEC rats } \\
\hline Basal & $1 \cdot 10^{\mathrm{b}}$ & 0.05 & $1.83^{\mathrm{C}}$ & 0.08 & $2 \cdot 28^{\mathrm{C}}$ & 0.04 \\
\hline Excess-histidine & $1 \cdot 31^{\mathrm{b}}$ & $0 \cdot 15$ & $2 \cdot 57^{\mathrm{b}}$ & 0.15 & $2 \cdot 71^{\mathrm{b}}$ & $0 \cdot 11$ \\
\hline \multicolumn{7}{|l|}{ Fischer rats } \\
\hline Basal & $3.08^{a}$ & 0.32 & $2 \cdot 21^{b c}$ & 0.21 & $3.02^{b}$ & 0.17 \\
\hline Excess-histidine & $1 \cdot 58^{\mathrm{b}}$ & $0 \cdot 12$ & $3 \cdot 71^{a}$ & 0.11 & $3 \cdot 47^{\mathrm{a}}$ & $0 \cdot 10$ \\
\hline \multicolumn{7}{|c|}{ Statistical significance of effect (ANOVA, $P$ ) } \\
\hline Diet & \multirow{2}{*}{\multicolumn{2}{|c|}{$\begin{array}{l}<0.01 \\
<0.001\end{array}$}} & \multicolumn{2}{|c|}{$<0.001$} & \multirow{2}{*}{\multicolumn{2}{|c|}{$\begin{array}{l}<0.001 \\
<0.001\end{array}$}} \\
\hline Strain & & & $<0$. & & & \\
\hline Diet $\times$ strain & \multicolumn{2}{|c|}{$<0.001$} & \multicolumn{2}{|c|}{$<0.05$} & \multicolumn{2}{|c|}{ NS } \\
\hline
\end{tabular}

LEC, Long-Evans Cinnamon.

$\mathrm{a}, \mathrm{b}, \mathrm{c}$ Mean values within a column with unlike superscript letters were significantly different $(P<0.05)$

* For details of diets and procedures, see Table 1 and p. 574

In addition to $\mathrm{Cu}$, the contents of other metals such as $\mathrm{Zn}$ and $\mathrm{Fe}$ in the liver of LEC rats were also much higher than those in Fischer rats (Sugawara et al. 1991b). The high concentration of $\mathrm{Zn}$ in the liver of LEC rats is considered to have a protective effect though the induction of metallothionein, which sequesters $\mathrm{Cu}$ in cells (Sugawara et al. $1991 b)$. Zn therapy is another treatment for Wilson's disease (Gitlin, 1998). Unfortunately, the $\mathrm{Zn}$ content in the liver of LEC rats was reduced by the excess-histidine diet (Table 3). This decrease in liver $\mathrm{Zn}$ content was also observed in another study, when we fed a diet containing D-penicillamine to LEC rats $(\mathrm{H} \mathrm{Xu}$ and Y Aoyama, unpublished results). We did not determine $\mathrm{Fe}$ concentrations in the present study. The excess $\mathrm{Cu}$ and Fe levels may facilitate the Fenton reaction to produce hydroxyl radicals in LEC rats (Suzuki et al. 1993) and Obata et al. (1999) reported that histidine has a protective effect on iron(II)induced hydroxyl radical generation in rat tissue.

Table 9. Serum alanine aminotransferase activity $(\mathrm{U} / \mathrm{I})$ in rats fed the basal or excess-histidine diet ${ }^{*}$

(Mean values with their standard errors for six rats per group)

\begin{tabular}{|c|c|c|c|}
\hline & \multicolumn{3}{|c|}{ Alanine aminotransferase } \\
\hline & Mean & & SE \\
\hline \multicolumn{4}{|l|}{ LEC rats } \\
\hline Basal & $80 \cdot 0^{\mathrm{a}}$ & & $15 \cdot 1$ \\
\hline Excess-histidine & $44 \cdot 8^{\mathrm{b}}$ & & $3 \cdot 7$ \\
\hline \multicolumn{4}{|l|}{ Fischer rats } \\
\hline Basal & $33 \cdot 1^{\mathrm{b}}$ & & 3.6 \\
\hline Excess-histidine & $46 \cdot 8^{\mathrm{b}}$ & & $6 \cdot 2$ \\
\hline \multicolumn{4}{|c|}{ Statistical significance of effect (ANOVA, $P$ ) } \\
\hline Diet & & NS & \\
\hline Strain & & $<0.05$ & \\
\hline Diet $\times$ strain & & $<0.05$ & \\
\hline
\end{tabular}

LEC, Long-Evans Cinnamon.

${ }^{a, b}$ Mean values within a column with unlike superscript letters were significantly different $(P<0.05)$.

* For details of diets and procedures, see Table 1 and p. 574
In LEC rats, excess $\mathrm{Cu}$ in the cell is considered to generate reactive oxygen radicals in the liver by catalysis via the Haber-Weiss reaction (Gutteridge \& Wilkins, 1983; Ding \& Chan, 1984; Mello Filho \& Meneghini, 1984). Among enzymatic defences, superoxide dismutase, catalase and glutathione peroxidase have been considered essential to the cell in removing oxygen radicals from tissues exposed to oxidative stress (Fridovich, 1978; Leibovitz \& Siegel, 1980). Yamamoto et al. (1999) have reported that the activities of catalase and glutathione peroxidase in the liver of LEC rats were markedly depressed. In the present study, the activities of superoxide dismutase (total, $\mathrm{Mn}$ - and $\mathrm{Cu}, \mathrm{Zn}$-), catalase and glutathione peroxidase in the liver of LEC rats were also significantly lower than those of Fischer rats when fed on the basal diet (Table 6). Significant declines in the activities of liver total and $\mathrm{Cu}, \mathrm{Zn}$-superoxide dismutase were observed in LEC rats fed on the excess-histidine diet (Table 6). It is possible that this might be due to the decreased concentrations of liver $\mathrm{Cu}$ and $\mathrm{Zn}$.

Abnormalities of lipid metabolism also have been observed in LEC rats (Tables 7 and 8). Taniguchi et al. (1991) reported that the lipid patterns of LEC rats are similar to those of choline-deficient rats, in which the liver may fail to transfer the newly formed triacylglycerol and cholesterol into the plasma with a resultant increase in liver triacyglycerol content and a decrease in serum lipid levels. However, the contents of liver lipids were not increased when LEC rats were fed on the excess-histidine diet (Table 7). Furthermore, the excess-histidine diet increased the levels of serum cholesterol and phospholipids in LEC rats (Table 8). It seems that excess dietary histidine also has positive effects on the abnormal lipid metabolism in LEC rats, but we have no adequate explanation as yet.

An increase in the activity of serum alanine aminotransferase is one of the signs of liver damage (Wroblewski $\&$ LaDue, 1956). When fed on the basal diet, the activity of this enzyme in LEC rats was significantly higher than that in Fischer rats. However, when fed on the excess-histidine diet, the activity of serum alanine aminotransferase in LEC rats significantly decreased to values similar to those of Fischer rats fed on the basal diet (Table 9). This result was consonant with the reduction in excess liver $\mathrm{Cu}$ in LEC rats by the excess-histidine diet.

In summary, the present study indicates that excess dietary histidine is effective in reducing the excess $\mathrm{Cu}$ accumulation in the liver and stimulates the urinary excretion of $\mathrm{Cu}$ in LEC rats. This result offers new possibilities for additional approaches to chelation therapy in patients with Wilson's disease. However, caution must be exercised as together with the reduction in liver $\mathrm{Cu}$ came a massive increase in urinary $\mathrm{Zn}$ loss and a reduction in liver $\mathrm{Zn}$. The preliminary results have also shown that excess dietary histidine may have a beneficial effect on the abnormal lipid metabolism in LEC rats.

\section{References}

Aebi H (1974) Catalase. In Methods of Enzymatic Analysis, 2nd ed., pp. 673-684 [HU Bergmeyer, editor]. New York: Academic Press. 
Aoyama Y, Takagi M \& Yoshida A (1999) Lipid alterations in the liver and serum of rats in histidine-excess and copper deficiency. J Nutr Sci Vitaminol 45, 773-783.

Aoyama Y, Tsuda T, Hitomi-Ohmura E \& Yoshida A (1992) Effect of dietary excess-histidine on fructose 1,6-bisphosphatase and 6-phosphofructokinase activities, and activation of fructose 1,6-bisphosphatase by basic amino acids in rat liver. Int J Biochem 24, 981-985.

Ding AH \& Chan PC (1984) Singlet oxygen in copper-catalyzed lipid peroxidation in erythrocyte membranes. Lipids 19, 278-284.

Duncan DB (1955) Multiple range and multiple F tests. Biometrics 11, $1-42$.

Folch J, Lee M \& Sloane-Stanley GH (1957) A simple method for the isolation and purification of total lipides from animal tissues. J Biol Chem 226, 497-506.

Forbes RM, Erdman JW Jr, Parker HM, Kondo H \& Keleson SM (1983) Bioavailability of zinc in coagulated soy protein (Tofu) to rats and effect of dietary calcium at a constant phytate : zinc ratio. J Nutr 113, 205-210.

Fridovich I (1978) The biology of the oxygen radical. Science 201, 875-880.

Gitlin N (1998) Wilson's disease: the scourge of copper. J Hepatol 28, 734-739.

Gutteridge JM \& Wilkins S (1983) Copper salt-dependent hydroxyl radical formation. Damage to proteins acting as antioxidants. Biochim Biophys Acta 759, 38-41.

Hitachi Ltd (1978) Instruction Manual, Model 170-50A Atomic Absorption Spectrophotometer. Tokyo: Hitachi Ltd.

Klein D, Lichtmannegger J, Heinzmann U \& Summer $\mathrm{KH}$ (2000) Dissolution of copper-rich granules in hepatic lysosomes by D-penicillamine prevents the development of fulminant hepatitis in Long-Evans cinnamon rats. $J$ Hepatol 32, 193-201.

Leibovitz BE \& Siegel BV (1980) Aspects of free radical reactions in biological systems: aging. J Gerontol 35, 45-56.

Li Y, Togashi Y \& Sato S et al. (1991) Spontaneous hepatic copper accumulation in Long-Evans Cinnamon rats with hereditary hepatitis. A model of Wilson's disease. J Clin Invest 87, $1858-1861$

Loudianos G \& Gitlin JD (2000) Wilson's disease. Semin Liver Dis 20, 353-364.

McCord JM \& Fridovich I (1969) Superoxidase dismutase: An enzyme function for erythrocuprein (hemocuprein). $J$ Biol Chem 244, 6049-6055.

Masuda R, Yoshida MC, Sasaki M, Dempo K \& Mori M (1988) High susceptibility to hepatocellular carcinoma development in LEC rats with hereditary hepatitis. Jap J Cancer Res 79, $828-835$.

Mello Filho AC \& Meneghini R (1984) In vivo formation of singlestrand breaks in DNA by hydrogen peroxide is mediated by the Haber-Weiss reaction. Biochim Biophys Acta 781, 56-63.

Mori M, Hattori A \& Sawaki M et al. (1994) The LEC rat: a model for human hepatitis, liver cancer, and much more. Am J Pathol 144, 200-204.

Muramatsu Y, Yamada T \& Miura M et al. (1994) Wilson's disease gene is homologous to hts causing abnormal copper transport in Long-Evans Cinnamon rats. Gastroenterology 107, 1189-1192.

Nagele U, Wahlefeld AW \& Ziegenhorn J (1985) Lipids: Fatty acids and derivatives. Triglycerides. Colorimetric method. In Methods in Enzymatic Analysis, 3rd ed., vol. 3, pp. 12-18
[HU Bergmeyer, J Bergmeyer and M Grassl, editors]. Deerfield Beach, FL: VCH Publisher.

Obata T, Aomine M \& Yamanaka Y (1999) Protective effect of histidine on iron(II)-induced hydroxyl radical generation in rat hearts. $J$ Physiol Paris 93, 213-218.

Paglia DE \& Valentine WN (1967) Studies on the quantitative and qualitative characterization of erythrocyte glutathione peroxidase. J Lab Clin Med 70, 158-169.

Rakela J, Vargas H \& Arenas J (2002) Is D-penicillamine useful in fulminant Wilson's disease? Liver Transpl 8, 502-503.

Reeves PH, Nielsen FH \& Fahey GC (1993) AIN-93 purified diets for laboratory rodent: Final report of the American Institute of Nutrition ad hoc Writing Committee on the reformulation of the AIN-76A rodent diet. J Nutr 123, 1939-1951.

Siedel J, Hagele EO, Ziegenhorn J \& Wahlefeld AW (1983) Reagent for enzymatic determination of serum total cholesterol with improved lipolytic efficiency. Clin Chem 29, $1075-1080$.

Smith PK, Krohn RI \& Hermanson GT et al. (1985) Measurement of protein using bicinchoninic acid. Anal Biochem 150, 76-85.

Snedecor GW \& Cochran WG (1989) Two-way classifications. In Statistical Methods, 8th ed., pp. 254-272. Ames, IA: Iowa State University Press.

Sone H, Maeda M \& Gotoh M et al. (1992) Genetic linkage between copper accumulation and hepatitis/hepatoma development in LEC rats. Mol Carcinog 5, 199-204.

Steen VD, Blair S \& Medsger TA (1986) The toxicity of D-penicillamine in systemic sclerosis. Ann Intern Med 104, 699-705.

Sugawara N, Sugawara C, Katakura M, Takahashi H \& Mori M (1991a) Harmful effect of administration of copper in LEC rats. Res Comm Chem Pathol Pharmacol 73, 289-297.

Sugawara N, Sugawara C, Katakura M, Takahashi H \& Mori M (1991b) Copper metabolism in the LEC rat: Involvement of induction of metallothionein and disposition of zinc and iron. Experientia 47, 1060-1063.

Suzuki K, Miyazawa N, Nakata T, Seo HG, Sugiyama T \& Taniguchi N (1993) High copper and iron levels and expression of Mn-superoxide dismutase in mutant rats displaying hereditary hepatitis and hepatoma (LEC rats). Carcinogenesis 14, 1881-1884

Takayama M, Itoh S, Nagasaki T \& Tanimizu I (1977) A new enzymatic method for determination of serum choline-containing phospholipids. Clin Chim Acta 79, 93-98.

Taniguchi M, Sugiyama T \& Taniguchi N (1991) Abnormal Lipid Metabolism in LEC Rats. In The LEC Rat, pp. 169-174 [M Mori et al. editors]. Tokyo: Springer-Verlag.

Togashi Y, Li Y \& Kang JH et al. (1992) D-Penicillamine prevents the development of hepatitis in Long-Evans Cinnamon rats with abnormal copper metabolism. Hepatology 15, 82-87.

Walshe JM (1956) Penicillamine, a new oral therapy for Wilson's disease. Am J Med 21, 587-595.

Wroblewski F \& LaDue JS (1956) Serum glutamic pyruvic transaminase in cardiac and hepatic disease. Proc Soc Exper Biol Med 91, 569-571.

Wu J, Forbes JR, Chen HS \& Cox DW (1994) The LEC rat has a deletion in the copper transporting ATPase gene homologous to the Wilson disease gene. Nat Genet 7, 541-545.

Yamamoto H, Hirose K, Hayasaki Y, Masuda M, Kazusaka A \& Fujita S (1999) Mechanism of enhanced lipid peroxidation in the liver of Long-Evans Cinnamon (LEC) rats. Arch Toxicol 73, 457-464. 